Before Wilde 
The publisher gratefully acknowledges the support of the Humanities Endowment Fund of the University of California Press Foundation. 


\section{Before Wilde}

Sex between Men

in Britain's Age of Reform

Charles Upchurch

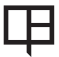

UNIVERSITY OF CALIFORNIA PRESS

Berkeley · Los Angeles · London 
University of California Press, one of the most distinguished university presses in the United

States, enriches lives around the world by advancing scholarship in the humanities, social sciences,

and natural sciences. Its activities are supported

by the UC Press Foundation and by philanthropic

contributions from individuals and institutions.

For more information, visit www.ucpress.edu.

University of California Press

Berkeley and Los Angeles, California

University of California Press, Ltd.

London, England

(C) 2009 by The Regents of the University of California

Library of Congress Cataloging-in-Publication Data

Upchurch, Charles, I969-.

Before Wilde : sex between men in Britain's age of reform / Charles Upchurch.

p. $\quad \mathrm{cm}$.

Includes bibliographical references and index. ISBN 978-0-520-25853-2 (cloth : alk. paper)

I. Gay men-Great Britain-History. 2. Gay men-Great Britain-Social conditions. 3. Men-

Sexual behavior-Great Britain-History-I9th century. 4. Homosexuality-Great BritainHistory-I9th century. 5. Sex-Great BritainHistory- I9th century. 6. Great BritainHistory- I9th century. 7. Great Britain-Social conditions-Igth century. I. Title.

HQ76.2.G7U63 2009

306.76'62094I09034-dc22 200803439I

Manufactured in the United States of America

$\begin{array}{llllllllll}\text { I } 8 & \text { I7 } & \text { I6 } & \text { I5 } & \text { I4 } & \text { I3 } & \text { I2 } & \text { II } & \text { IO } & \text { O9 }\end{array}$

IO $\begin{array}{lllllllll}9 & 8 & 7 & 6 & 5 & 4 & 3 & 2 & \text { I }\end{array}$

This book is printed on Natures Book, which contains $30 \%$ post-consumer waste and meets the minimum requirements of ANSI/NISO Z39.48-I992 (R I997)

(Permanence of Paper). 
For Fred 
